\title{
TERRITORIAL INTENSIVE PRODUCTS AS PROMOTERS OF REGIONAL TOURISM. THE CASE STUDY OF DOURO SKINCARE
}

\author{
L. CARVALHO ${ }^{1, *}$, C. SOUTINHO ${ }^{2}$, T. PAIVA ${ }^{3}$, S. LEAL ${ }^{4}$
}

${ }^{1}$ Escola Superior de Ciências Empresariais, Instituto Politécnico de Setúbal \& CEFAGE, ${ }^{1}$ Universidade de Évora,

${ }^{2,3,4}$ PEEP - Educar para Empreender, ${ }^{3}$ Unidade de Investigação de Desenvolvimento do Interior, ${ }^{4}$ Instituto Politécnico da Guarda \& Departamento de Química e Bioquímica, FCUL

luisam.carvalho@uab.pt

Received 22/10/2016 - Accepted 13/05/2018

DOI: $10.15628 /$ holos.2018.5243

\begin{abstract}
The case study explores the growth and regional involvement of Douro SkinCare ${ }^{1}$, a company created by women that operates in the field of selective Biological Cosmetics through the creation, development and production of cosmetic lines that are based on emblematic raw materials of the Douro Region, one of the oldest wine-growing areas with more history in the world, located in the north of our country, Portugal. It uses Douro grapes and PORT WINE DNA ${ }^{\text {TM }}$ (Douro Nuclear Aroma), created from the first port wine from entirely organic production to develop cosmetic lines produced with endogenous products. The territorial intensive products (TIP) are associated directly with the region and are intensively endogenous. TIPs are indirectly related with local tourism as a trademark. This case study uses a qualitative methodology, based on YIN (1998). This case illustrates how a brand can contribute for regional development and expansion by a small female business. It also highlights the role of the entrepreneurs in introducing modernity, innovation and product diversification to allow such a small firm to reach new markets. This research could bring new insights and relevant proposals to the relation between TIPs, female entrepreneurship, tourism and regional development.
\end{abstract}

KEYWORDS: Female entrepreneurship; TIPs; Tourism; Regional brand; Sustainability.

\section{PRODUTOS TERRITORIALMENTE INTENSIVOS COMO PROMOTORES DO TURISMO NUMA PERSPECTIVA REGIONAL. O CASO DO DOURO SKINCARE}

\section{RESUMO}

Este estudo apresenta o caso da empesa DouroSkinCare. Esta empresa foi fundada por uma equipa constituída por mulheres e produzem uma gama de cosméticos biológicos produzidos com produtos endógenos da região vitivinícola do Douro situada no norte de Portugal. O Douro é a região vitivinícola mais antiga do mundo e a marca Douro é reconhecida mundialmente. As empreendedoras criaram os seus produtos usando as uvas do Douro e o "Port Wine DNA" que é um aroma nuclear do Douro. Esta marca está associada a um grupo de produtos denominados pela literatura por Produtos Territorialmente Intensivos (TIPS). Neste âmbito os TIPs estão indiretamente relacionados com o turismo e com a marca regional. O estudo usa uma metodologia qualitativa baseada no YIN (2004). Este caso ilustra como a marca pode contribuir para o desenvolvimento regional e para o desenvolvimento de um negócio criado e gerido por mulheres. Também aponta para a influência do perfil das empreendedoras no desenvolvimento e posicionamento da empresa no mercado global, evidenciando a sua preocupação com a inovação, internacionalização, modernidade e sofisticação como forma de conquistar novos mercados.

PALAVRAS-CHAVE: Empreendedorismo feminino; TIPs; Turismo; Marca Regional; Sustentabilidade. 


\section{LITERATURE REVIEW}

\subsection{Tourism and TIPs}

Today TIPs are part of the heritage in a territory and could provide a special cultural tourism experience. In the last few years the Council of Europe for Cultural Routes has encouraged the creation and exploitation of some itineraries, as cultural routes, such as 'The Routes of the Olive Tree' or the "Iter Vitis - Wine Routes in European countries". These thematic routes promote thematic tourism and the protection of cultural heritage through the utilization of typical products (ASERO and PATTI, 2009). The touristic potential of these typical products is higher when they are identified with quality labels and brands that protect their identity and are associated with the endogenous features from the territory where there are produced.

In the case of the wine tourism it's possible to identify different stages associated with wine production, since the grape plantations and their landscape (for instance in the case of Portugal, Douro is a United Nations Educational, Scientific and Cultural Organization (UNESCO) world heritage and it was the first wine Demarcated Region in the world and several tourists come just to see this particular landscape); to production in the wineries, taste and gastronomy; contact with the farms where the wine is produced and all the environment and experiences provided within rural tourism (CARVALHO, 2014).

OHE and KURIHARA (2013) suggest that local food production and rural tourism are joint products, and wine is a predominant TIPs associated with rural tourism in numerous researches. Table 1 presents a state of art of TIPs and tourism.

Table 1. State of art: TIPs and tourism

\begin{tabular}{|c|c|c|}
\hline Topic & Sub topic & Publication \\
\hline \multirow[t]{9}{*}{ Local food and tourism } & $\begin{array}{c}\text { Rural development/rural } \\
\text { tourism }\end{array}$ & $\begin{array}{c}\text { RENKO, RENKO, \& POLONIJO, } \\
\text { 2010; SIMS, 2009, 2010; VAZ, } \\
\text { NIJKAMP,\& RASTOIN, } 2009\end{array}$ \\
\hline & Authenticity & SIMS, 2009 \\
\hline & Rural cultural heritage & $\begin{array}{l}\text { SZLANYINKA, 2009; OHE \& } \\
\text { CIANI, } 2011\end{array}$ \\
\hline & Food tourism & $\begin{array}{l}\text { HALL, SHARPLES, MITCHELL, } \\
\text { MACIONIS, \& CAMBOURNE, } \\
2003\end{array}$ \\
\hline & Wine tourism & $\begin{array}{c}\text { HALL, SHARPLES, CAMBOURNE, } \\
\text { \& MACIONIS, 2000; KIM, YUAN, } \\
\text { GOH, \& ANTUN, } 2009\end{array}$ \\
\hline & Social effects & $\begin{array}{c}\text { EVERETT \& AITCHISON, 2008; } \\
\text { BRANDTH \& HAUGEN, } 2011\end{array}$ \\
\hline & $\begin{array}{c}\text { Rural development/rural } \\
\text { tourism }\end{array}$ & $\begin{array}{l}\text { RENKO, RENKO, \& POLONIJO, } \\
\text { 2010; SIMS, 2009, 2010; VAZ, } \\
\text { NIJKAMP,\& RASTOIN, } 2009\end{array}$ \\
\hline & Culinary tourism & $\begin{array}{l}\text { MONTANARI \& STANISCIA, } \\
\text { 2009; HORNG \& TSAI, } 2010\end{array}$ \\
\hline & $\begin{array}{l}\text { Organic agriculture and agri- } \\
\text { ecotourism }\end{array}$ & KUO, CHEN, \& HUANG, 2006 \\
\hline
\end{tabular}

Source: OHE and KURIHARA (2013) 
Table 1. State of art: TIPs and tourism (continued)

\begin{tabular}{|c|c|c|}
\hline Rural tourism & & $\begin{array}{l}\text { BÉLISLE, 1983; OHE, 2008; } \\
\text { TELFER \& WALL, } 1996\end{array}$ \\
\hline \multirow[t]{3}{*}{$\begin{array}{c}\text { Economic effects of local food } \\
\text { and tourism }\end{array}$} & $\begin{array}{c}\text { Differentiation of tourism } \\
\text { destinations }\end{array}$ & HAVEN-TANG \& JONES, 2006 \\
\hline & Food consumption by tourists & $\begin{array}{l}\text { KIM, EVES, \& SCARLES, 2009; } \\
\text { SKURAS, DIMARA, \& PETROU, } \\
2006\end{array}$ \\
\hline & $\begin{array}{l}\text { Backward economic linkage } \\
\text { Hedonic pricing approach }\end{array}$ & $\begin{array}{c}\text { TELFER \& WALL, } 2000 \\
\text { OHE \& CIANI, } 2011\end{array}$ \\
\hline \multirow[t]{5}{*}{ Economies of scope } & Agricultural and rural field & AZZAM, 1998; CHAVAS, 2008; \\
\hline & & $\begin{array}{l}\text { CHAVAS, CHAMBERS, \& POPE, } \\
\text { 2010; FERNANDEZ-CORNEJO, } \\
\text { GEMPESAW, ELTERICH, \& } \\
\text { STEFANOU, 1992; HARTARSKA, } \\
\text { PARMETER, \& NADOLNYAK, } \\
\text { 2011; MELHIM \& SHUMWAY, } \\
2011\end{array}$ \\
\hline & Agricultural cooperatives & $\begin{array}{c}\text { KONDO, 1997; SCHROEDER, } \\
1992\end{array}$ \\
\hline & Non-agricultural field & $\begin{array}{l}\text { CHAVAS, BARHAM, FOLTZ, \& } \\
\text { KIM, 2012; PROIR, } 1996\end{array}$ \\
\hline & Theoretical development & $\begin{array}{l}\text { BAUMOL, PANZAR, \& WILLIG, } \\
\text { 1988; CHAVAS \& KIM, 2007; } \\
\text { PANZAR \& WILLIG, } 1981\end{array}$ \\
\hline
\end{tabular}

Source: OHE and KURIHARA (2013)

\subsection{Brand and marketing linked with regional products}

Brand as defined by KOTLER et al. (1994), is a name or image to establish a product position as the property of a specific brand owner that gives them value. It serves also to differentiate a product which benefits consumers in a way that is more than its functional characteristics (CHERNATONY and MACDONALD, 2003). There are diverse types of brand that do not easily equate with the classic notion of a brand owned and operated by a single enterprise (CHARTERS et al., 2011). That is the case of umbrella, corporate, leader brands and the placerelated brands (country, regional and destination brands).

These territorial brands are not created through consumer orientation but are rather production orientation results, as core characteristics of the product depend on the environment (CHARTERS and SPIELMANN, 2014). Regional or local brands are based in one area and have the advantage of association with a region of origin, especially when the region of origin is particularly important as a cue for high added-value products (VAN ITTERSUM et al., 2003).

This type of brands may include products which trade off a region or place as well as products which are situated in a single region (VAN ITTERSUM et al., 2003), like "Douro Region". However, the products are not defined by the collective memberships of the regional brand, nor they have to be produced in the region with an indissoluble environmental relationship to it (CHARTERS et al., 2011).

As observed by PERROUTY et al. (2006), the region of origin may serve as cue to link product benefits with a region and in some situations, consumers may prefer to buy those products. This factor is especially true for more highly involved consumers. 
The theoretical and empirical literature on consumer perceived brand benefits suggests classifying the benefits according to different dimensions: functional benefit (SHETH et al., 1991; de CHERNATONY, 1993), price (ZEITHAML, 1988; DODDS et al., 1991), social benefit (SHETH et al., 1991; AMBLER, 1997; BHAT and REDDY, 1998; LONG and SCHIFFMAN, 2000), and emotional benefit (SHETH et al., 1991; DE CHERNATONY, 1993; AMBLER, 1997; BHAT and REDDY, 1998; LONG and SCHIFFMAN, 2000). So, the importance of that countries, regions, places, and other geographical entities behave like brands is gaining acceptance and value for regional branding (PAPADOPOULOS and HESLOP, 2002). There are studies that confirmed that national and other places images are powerful stereotypes that influence behaviour in all types of target markets.

\subsection{Entrepreneurship and female entrepreneurship}

HUGHES et al. (2012) referred that the field of women's entrepreneurship research has quickly moved on from what was classified in 2006 as the "the early childhood stage" (DE BRUIN et al., 2006) to what they describe in 2012 as being "on the brink of adolescence".

As the field has acquired maturity, there have been calls for more attention to the heterogeneity evident among female entrepreneurs (DE BRUIN et al., 2006; HUGHES and JENNINGS, 2012; CARVALHO and WILLIAMS, 2014) and to explanations emphasizing the different contexts in which these women are embedded (BRUSH et al., 2009; HUGHES and JENNINGS, 2012). HUGHES et al. (2012, p.432), for example, have suggested that more research attention be given to "new sites of women's entrepreneurship, especially new regions, national contexts, and industries" and the present study sets out to be a contribution towards addressing this need.

In 2012, there were 40.6 million entrepreneurs active in Europe-37, of whom 29\% were women (11.6 million). The percentage of women entrepreneurs was slightly higher in the European Union (EU-28) at 31\%. In EU-28, around 10.3 million women entrepreneurs were active compared to 22.8 million men entrepreneurs (EUROPEAN COMMISSION, 2014). In 2012, the entrepreneurship rate for women (percentage of women entrepreneurs in the total number of women in the active labour force) was $10 \%$ for Europe-37 and for EU-28. The rates for men were higher at $20 \%$ and $19 \%$, respectively for Europe-37 and EU-28 (EUROPEAN COMMISSION, 2014). Portugal was one of the five countries with higher women entrepreneurs' rate in 2012, with Greece, Albania, Italy and Croatia. WES Report 2012 (EUROPEAN COMMISSION, 2013) states that, in Portugal, the number of self-employed women has been increasing for several years now. According to the National Institute of Statistics and the employment statistics, in 2012, some 976,0 thousand people were self-employed, of which 366,0 (16,7\%) were women and 610,0 (25,0\%) were men. However, seems like there are good practices in the field to promote female entrepreneurship focused by National Plans of Equality (EUROPEAN COMMISSION, 2012).

The same WES Report 2012 (EUROPEAN COMMISSION, 2013) referred there are good practices promoted by associations of female entrepreneurs and some NGOs, but also other programmes like the one promoted by the Commission for Citizenship and Gender Equality (CIG), were CIG established a protocol with the CASES - Cooperative António Sérgio for Social Economy, in the context of the National Microcredit Programme ${ }^{2}$.

\footnotetext{
${ }^{2}$ This programme is intended to stimulate job creation and entrepreneurship among population that has greatest difficulty in accessing the labor market, thereby facilitating access to credit and to technical support for the creation and consolidation of business projects (WES Report 2012, EUROPEAN COMMISSION, 2013).
}

HOLOS, Ano 34, Vol. 04 
Female-run enterprises are steadily growing all over the world and contribute for the growth of national economies.

The decision to undertake is often referred to by entrepreneurs to have occurred, apparently by accident. However, in fact this comes from external, environmental and social factors, personal skills or a sum of all these factors, which play a key role in the emergence of a business idea and growth of a new company (IFDEP, 2014).

The promotion of female entrepreneurship as combating inequality, as well as a way of developing an economic potential to explore, has been, for some years, a goal of most European governments and institutions. Education is increasingly focused on entrepreneurship, it facilitates the adoption of entrepreneurial attitudes and leads to increased entrepreneurial activity as a means of mobilization of women in economic life. Also, the European Union has played a crucial role in supporting women's entrepreneurship, promoting self-employment and supporting innovative solutions through financial and training mechanisms (IFDEP, 2014). The promotion of female entrepreneurship is vital, not only for enhancing e competitiveness and innovation in the global economy, but also by encouraging self-employment / business, for the prevention and protection against unemployment (IFDEP, 2014).

According to DE VETTE (2001) that results show that there are differences between female opportunity and female necessity entrepreneurs. For example, the effect of knowing an entrepreneur is found to be significant for female opportunity entrepreneurs but not for female necessity entrepreneurs. This variable could stimulate or discourage opportunity and necessity entrepreneurs to start a business.

The 2012 Global Entrepreneurship Monitor (GEM) Women's Report shows that women's participation in entrepreneurship differs around the world, as does their impact on job creation and innovation. Women entrepreneurs in Developing Europe are typically young, well-educated and wealthy. They often partner to start business and they employ others. They have ambition to grow and sell internationally. With all this potential it's a wonder there aren't more women entrepreneurs in Developing Europe.

Entrepreneurship rates among women were low in Developed Europe, lower than that of their male peers, although with less a gender gap than was reported in Developing Europe. More than half the women entrepreneurs were operating consumer-oriented businesses; in contrast, over half of the male entrepreneurs in this region were running transforming or business services operations. Women were also more likely to be running single-founder businesses. Like their lessdeveloped neighbouring economies, Developed Europe has highly educated women entrepreneurs, who are more likely than their male counterparts and non-entrepreneurial women to have a college degree. Internationalization is high among women entrepreneurs in this region, although not as high as in Developing Europe (which is about $50 \%$ higher) nor as high as their male equivalents. Perhaps more surprising, however, is the low growth aspirations among women entrepreneurs in this region; only $14 \%$ projected to add six or more employees in the next five years: lower than their male counterparts and little more than half that of women in Developing Europe.

Few women entrepreneurs in Developed Europe report being motivated by necessity, signalling a lack of a compelling need for starting businesses. In addition, women in this region report among the highest regional averages on fear of failure, which may especially deter those with opportunity motives. At the same time, when women in this region do start, they more often do it alone, without co-founders. They often operate direct-to-consumer businesses, and they 
have little appetite for growth. Perhaps the vestiges of the economic downturn in this region continue to weigh heavily on any entrepreneurial ambitions' women may have. Concurrently, women in this region may have many alternative pursuits: some of which are perceived more attractive than entering into entrepreneurship.

\section{METHODOLOGY}

This is a descriptive study where we have used interviews to design a case study. This case study uses a qualitative methodology, based on YIN (2004) to select and analyse information collected by the interviewers and other secondary information sources. According to YIN (2004) case study research enables to investigate important topics not easily covered by other methods. Conversely, other methods cover many topics better than a case study does. Firstly, the case study method is pertinent when the research addresses either a descriptive question (what happened?) or an explanatory question (how or why did something happen?). Secondly, it is useful when we want to illuminate a particular situation, to get a close (i.e., in-depth and first-hand) understanding of it.

\begin{tabular}{|c|c|c|}
\hline Step & Activity & Reason \\
\hline Getting Started & $\begin{array}{l}\text { Definition of research question: } \\
\text { How Territorial Intensive Products } \\
\text { promote regional tourism? }\end{array}$ & $\begin{array}{l}\text { Focuses efforts: } \\
\text { TIPS and tourism; Female entrepreneurship; } \\
\text { female entrepreneurial profile; regional } \\
\text { development }\end{array}$ \\
\hline Selecting Case & $\begin{array}{l}\text { Specific population: } \\
\text { Douro SkinCare }\end{array}$ & $\begin{array}{l}\text { Local firm that use local products to produce } \\
\text { innovative products (managed by women) }\end{array}$ \\
\hline $\begin{array}{l}\text { Entering the } \\
\text { Field }\end{array}$ & $\begin{array}{l}\begin{array}{l}\text { Flexible and opportunistic data } \\
\text { collection }\end{array} \\
\end{array}$ & $\begin{array}{l}\text { Allows investigators to take advantage of } \\
\text { methods and unique case features }\end{array}$ \\
\hline Analysing Data & Within-case analysis & $\begin{array}{l}\text { Gains familiarity with data and preliminary } \\
\text { theory generation } \\
\text { Cross-case pattern search using divergent }\end{array}$ \\
\hline $\begin{array}{l}\text { Shaping } \\
\text { Hypotheses }\end{array}$ & $\begin{array}{l}\text { Iterative tabulation of evidence for } \\
\text { each sharpens construct definition, } \\
\text { validity, and construct measurability } \\
\text { replication, not sampling, logic across }\end{array}$ & $\begin{array}{l}\text { Confirms, extends, and sharpens theory cases } \\
\text { Search evidence for "why" behind builds } \\
\text { internal validity relationships }\end{array}$ \\
\hline $\begin{array}{l}\text { Enfolding } \\
\text { Literature }\end{array}$ & $\begin{array}{l}\text { Comparison with conflicting literature } \\
\text { Comparison with similar literature }\end{array}$ & $\begin{array}{l}\text { Builds internal validity, raises theoretical level, } \\
\text { and sharpens generalizability, improves } \\
\text { construct definition, and raises theoretical } \\
\text { level construct definitions }\end{array}$ \\
\hline $\begin{array}{l}\text { Reaching } \\
\text { Closure }\end{array}$ & Theoretical saturation when possible & $\begin{array}{l}\text { Ends process when marginal improvement } \\
\text { becomes small }\end{array}$ \\
\hline
\end{tabular}

According to EISENHARDT (1989) building theory from case study research implies following certain steps. Table 2 presents the methodological guide for this research based on guidelines provided by EISENHARDT (1989).

We will use qualitative evaluation methods during the development of the investigation programme. Interviews are particularly useful for getting the story behind a participant's experiences. The interviewer can pursue in-depth information around the topic (MCNAMARA, 1999). 
There are several types of interviews, namely: informal, conversational interview; general interview guide approach; standardized, open-ended interview; and closed, fixed-response interview. ${ }^{3}$ The type of interview that we used was the general interview guide approach. In annex 1 it is possible to find the guide used in the interviews and Table 3 identifies the interviewees.

Table 3. Interviewees.

\begin{tabular}{|c|c|c|c|c|}
\hline Interviewee & Function & $\begin{array}{c}\text { Type of } \\
\text { interview }\end{array}$ & $\begin{array}{c}\text { Interview } \\
\text { date }\end{array}$ & Place \\
\hline Mariana Andrade & Director. Founder & Face to face & 2016.07.05 & Matosinhos \\
\hline Marta Enes & Brand manager & Face to face & 2016.07.05 & UPTEC - Porto \\
\hline Susana Cruz & Regulatory affairs & Skype & 2016.07.12 & $\begin{array}{l}\text { DGESTE } \\
\text { North/London }\end{array}$ \\
\hline
\end{tabular}

All interviews were audio recorded and useful for the analysis and we have used semistructured interviews that contain components of structured and unstructured interviews. We prepared a set of the same questions to be answered by all interviewees, however, additional questions were asked during interviews to clarify and/or further expand certain issues.

Among the main advantages of semi-structured interviews, we can include the following: (i) the possibility of access to richer information (contextualized through the words of the interviewees and their perspectives); (ii) the possibility of the researcher to clarify some aspects following the interview that structured interview or questionnaire does not allow; and (iii) the possibility of collecting many important data that can generate quantitative and qualitative information.

\section{CASE STUDY}

This section presents the case study selected "Douro SkinCare".

\subsection{Brief description of Douro SkinCare}

Douro Skincare company is intended to act in the area of selective cosmetics, through the creation, development and production of products and brands which have high quality standards and meet the required European regulations and market demand.

\footnotetext{
${ }^{3}$ https://en.wikipedia.org/wiki/Interview_(research), retrieved on July 29, 2016.

Informal, conversational interview - no predetermined questions are asked, in order to remain as open and adaptable as possible to the interviewee's nature and priorities; during the interview the interviewer "goes with the flow".

General interview guide approach - the guide approach is intended to ensure $t h$ at the same general areas of information are collected from each interviewee; this provides more focus than the conversational approach, but still allows a degree of freedom and adaptability in getting the information from the interviewee.

Standardized, open-ended interview - the same open-ended questions are asked to all interviewees; this approach facilitates faster interviews that can be more easily analysed and compared.

Closed, fixed-response interview - where all interviewees are asked the same questions and asked to choose answers from among the same set of alternatives. This format is useful for those not practiced in interviewing.
} 
Through a Business-to-Business (B2B) model, it focuses on innovation and technology, enhancing the parallel strand of biological products and raw materials, environmental sustainability and social responsibility. Increasing the promotion of the products and concepts it became into a "fusion cosmetic" as result, by valuing the Northern Country emblematic raw materials from the Douro region, especially those that give rise to Port Wine.

\subsection{Profile of female entrepreneurship}

The company was founded three years ago and the Director of the company is the oldest associate, a 38-year-old woman, while the remaining members are 26 and 30 years old.

Before the creation of this company only one of the partners had experience in setting up a business. She had created a business in the consulting area.

As for the fact of being female entrepreneurs, all consider that it may not differ in terms of management and decision, but, in certain situations, they might be not received in the same way as they would probably be if they were men, mainly in terms of credibility (the founder of the company was who most highlighted this aspect).

All members took the course of Pharmacy and worked in the area before embracing the opportunity to create or be part of this company, and the founding partner was the one who had more experience in the field.

None of them had any family influence and consider that female entrepreneurship in Portugal is growing, fortunately but at a very low rate when in comparison to male entrepreneurship. For instance, they were the only exclusively female startup incubated in UPTEC (Parque de Ciência e Tecnologia da Universidade do Porto).

With regard to risk management they all agree that there are enough risks in setting up any business and this one in particular. They gave the example that a technology company could provide some services and have a faster return, while for the creation of this company a large initial investment was needed without even knowing if customers would like the fragrance, the aromas, and all products of the created line of cosmetics. Fortunately, after just one year, the brand is being well received and the risk paid off.

\subsection{Process of business creation}

The idea came up when the founding partner was in a SPA of a hotel in front of river Douro in Oporto and noticed that all the cosmetics that were being used belonged to a foreign brand. That was when she first identified a business opportunity. The founding partner already knew some lesser known brands that sold well online and that resulted from raw materials from certain regions, that is, having a value attached, and it attracted the buyers' attention. She was not feeling motivated at work at the time due to a company merger and that was when she felt the need to change and create a new product and a new professional activity came to reality.

Because she liked the Douro region a lot she thought that a range of cosmetic products could be developed from raw materials of this iconic region of northern Portugal. Given the characteristics of the region and its products, mainly Port Wine, she came up with the idea of using vinotherapy but innovating the concept". 
Regarding the technical part of the idea, the first step was to contact the manufacturers to see what were the raw materials that they would have interest in using, which resulted in Port Wine, including the seeds of grapes.

The allocation of human resources came primarily because they all knew each other, had similar ideas and had the same academic background, being the gender just a coincidence. One of the members is working in the technical / operational part, another works on the regulatory part and the founding partner manages the business and idealizes the cosmetic lines and new products. They point out that part of the investigation was the result of a partnership with the University of Porto through its Faculty of Engineering. A team of professors had investigated the process of extracting alcohol from beer keeping the aromas. And that was when they came up with the idea that the same process to be applied to Port Wine, keeping the aroma.

They have come across various barriers along their path. The first one was financial as usual. The fact of having to arrange financing, competing projects, was very challenging, but they managed to overcome this phase after having applied to QREN (Quadro de Referência Estratégica Nacional) funds, also a microcredit (who helped in the production part because they could not get the product done on time, and a SME investment

Since in Portugal the technology involved in cosmetics production was not very advanced yet, it was difficult to find the appropriate partners to produce the formulas Douro Skincare had created. It was only at the third attempt and after an international experience in the United Kingdom that they managed to find a producer in Portugal and it was possible to stabilize the partner. Another obstacle that arose from the company's sustainable packaging requirements was the need to buy bottles with specific characteristics, therefore, to buy only 500 bottles would be very expensive and they needed to overcome another obstacle. They managed to overcome this difficulty, after the first failed experiment that resulted from their own experience, because they analysed not only the budget they had, but ultimately the quality of the final product. For that they requested samples in order to decide whether it was really what they wanted for the products.

In short, the main obstacles are those that arise out of the business plan that is made in advance. They suffered a setback when they hired a carrier and the glass packaging was not properly assured, that was when almost half of the samples were broken. Thus, they had to balance the investment and find the money to cope with the waiting period required for the production of new glass bottles, through the development of other products for other companies. It was this business decision that allowed them to cope with the current expenses but it also what made the company deviate a little from the concept of DVine, to which they have manage to return to within a year.

\subsection{Realize the relation between TIPS and tourism}

This product is manufactured with local raw materials, such as biological Port Wine, bottled, certified and sealed thus making the Douro Brand completely associated with the Douro SkinCare Brand.

One of the entrepreneurs said "we use local raw materials, to establish a direct relation with Douro region. And if we use local products in the SPAS, we establish a stronger relation with the region besides the landscape". 
However, other entrepreneur, revealed difficulty in limiting the product to the region, when she said, "we selected Ana Moura (Portuguese well-known Fado singer) as the brand ambassador. She refers that they wouldn't want that DVine were a line of regional products. They intended to promote a sophisticated and modern line of fusion cosmetics. The product is more than a cosmetic that uses an extract from a pip of an autochthonous grape of the Douro".

They use Porto Wine and grape extracts due to the fact that these two components are certified products subjected to a rigorous quality control, it is not a handmade product. The product is developed through a R\&D process that verifies in all phases of the product development and production the quality of the product and of the raw materials with suppliers.

Concerning the impact of Douro SkinCare in local economy, they do not have enough data to register the impact of the firm on local economy yet, however they reveal some perceptions due to their participation in international fairs and events that took place in several countries (France, Brazil, Japan, etc.) where people were curious about the cosmetics made with grapes and Port Wine and they wanted to know where Douro region was and how they could visit the region. So indirectly they promote Douro Region through their products when referring to the raw materials origin and its beauty.

With Douro as a brand could create more synergies however the market approach of the firm is broader. They have already established partnerships with hotels; they have already sent samples to an international hotel chain that detains hotels in the region but also in other countries, to provide amenities. Sometimes local hotels and pharmacies request products more directed to the tourist market, such as soaps or candles, that the company is considering but however for the moment, the company promotes a structured line of beauty products.

Nonetheless, the association with the Douro regional as a brand also creates some barriers. They had some problems in using the brand Port Wine. Initially they wanted to use the name Port Wine DNA - Douro Nuclear Aroma, playing with the words of human DNA, but they were just allowed to use Douro Nuclear Aroma and they couldn't register the brand due to the barriers associated with "Protected denomination of the region" that limited the disclosure.

Concerning sales, so far and since the beginning September of 2015 they sold 100 thousand Euros. The figures of 2016 are not closed but they expect to have tripled that value.

\subsection{Understand how they develop the brand and their relationship with region}

The marketing strategy of Douro SkinCare is based on the definition of the brand concept. It's a B2B2C business in which the privileged relation and contact is with distributors and intermediaries, and the brand has little connection with the final consumer, in spite of the business responsibility in the product image and positioning definition. The uniqueness and product differentiation are essential for a clear positioning and directed to a chic and demanding woman that is not subdued to normal elements.

The products also have in its brand the association to the Douro region and its wine for the obvious relationship between the natural beauty of the region and the attractiveness that the products intend to offer along with the uniqueness of Port Wine aromas and colors added to the products and their packaging. Even the lines of the fusion cosmetics follow a specific glossary related to wine using words such as harvest to identify the lines and the age target of the creams, for example. 
The completion of the differentiation of Douro SkinCare is not made through price since they are not able of mass production and consequently they try to link their products as selective cosmetics and not derma cosmetics in spite of using pharmacies as retailers. The difference between the two is that the latest is linked to a medicinal perspective, thought to be prepared to protect several types of derma. The selective cosmetics intend to offer beauty, in a healthy way, in this case mainly through natural and sustainable arguments, adding performance ingredients to biological raw materials, but they are not mass-market products.

The product correlation with the environment is very important for the brand concept and consequently a concern in acting accordingly to the natural environment preservation is followed, balanced with a profitable perspective of business management. Therefore, some solutions were found, since the wine production and fragrance used to the packaging characteristics. But the environmentally sustainable allegation doesn't have, yet, a strong response from the market, which make these options more difficult to follow.

The brand is making an investment in a more direct approach to the market through online sale, with Facebook and Instagram social platforms and demonstrations in the pharmacy retailers.

\subsection{Future and challenges}

Douro SkinCare has two major goals for the future which are the sales increase in Portugal and the internationalization.

They intend to upgrade the national market by having visibility and a strong distribution, consolidating the business value chain and the importation of the products production to Portugal.

To export is very important and determinant for the growth of the company but they are aware of the differentiation between the regulations of the countries that they have to adapt to and the cultural issues they have to incorporate into the products in order to be accepted. These concerns are due to the goal to export to the Middle East countries, but also Japan, Brasil or the USA.

Not only market diversification is essential but also product variety. They are already testing some new products to complement the actual offer with the constant concern of listening to the market desires and needs. Still the company is only three years and is consolidating its market position.

\section{DISCUSSION OF RESULTS AND CONCLUDING REMARKS}

The paper explores the growth and regional involvement of Douro SkinCare, a company created and managed by women that operates in the field of selective Biological Cosmetics produced with raw materials of the Douro Region. Douro wine is a territorial intensive products (TIP) directly associated with the region and intensively endogenous. These Biological Cosmetics produced with Douro grapes and other endogenous materials, could be (or not) a TIPs? The discussion provided by the case study concludes that DouroSkinCare are directly related with Douro trademark, however follow a global approach that dispel the association with regional tourism. Although this is clear the product doesn't have a handcraft concept, on the contrary they pretend to be a sophisticated option.

Literature review underlines a positive relation between TIPS and tourism (OHE and KURIHARA, 2013; see table 1), however Douro Skin Care doesn't have a direct relation with 
tourism and regional development due to their market target. This firm aims to achieve global markets with a product with high quality standards and developed with rigorous process and intensive R\&D. Nevertheless, the association with Douro could influence indirectly the promotion of the tourism in this region.

Yet, it is possible to find a relationship between Douro region as a brand and the consumers mainly in the sustainable perspective but the mental connection to the region is already evident. As argued by several authors (e.g. Van ITTERSUM et al., 2003; CHARTERS and SPIELMANN, 2014) we may observe a direct connection with Douro region and its two most important assets: beauty and nature. In this sense we may call the business and its products clearly trying to take advantage of a well know region, linked to the main raw material used and a strong mental and emotional connection with the splendor and natural environment of the region. There is a stronger relationship to develop between these allegations and the consumers, mainly in the sustainable perspective but the mental connection to the region is already evident.

Additionally, it's also important to note that the founders are women entrepreneurs, young and educated, following the pattern described in literature. Besides, they have the ambition to grow and sell internationally, and reject the possibility of their products are associated with regional handcraft products. However, the company is recent and for now it is not possible to establish a link between entrepreneurship and gender or identify female patterns in the management style.

In summary, this is an exploratory study that allows us to identify some clues and future research lines. As a result of the case study discussion, the principal remarks could be organised attending to the objectives of this research and allows us to propose 3 hypotheses for future research (Table 4).

Table 4. Objectives and hypotheses for further research.

\begin{tabular}{|c|c|c|}
\hline General Objective & Specific Objectives & Hypotheses \\
\hline \multirow{4}{*}{$\begin{array}{l}\text { Understand how } \\
\text { TIPs promote } \\
\text { regional tourism }\end{array}$} & $\begin{array}{l}\text { Recognize the profile of female } \\
\text { entrepreneurship }\end{array}$ & \multirow[t]{2}{*}{$\begin{array}{l}\text { H1: Female entrepreneurial profile influences } \\
\text { positively entrepreneurial project }\end{array}$} \\
\hline & $\begin{array}{c}\begin{array}{l}\text { Understand the process of business } \\
\text { creation }\end{array} \\
\end{array}$ & \\
\hline & $\begin{array}{c}\text { Realize the relation between TIPS and } \\
\text { tourism }\end{array}$ & $\begin{array}{l}\mathrm{H} 2: \text { The entrepreneurial project using TIPs } \\
\text { influences positively regional tourism }\end{array}$ \\
\hline & $\begin{array}{c}\text { Understand how they develop the } \\
\text { brand and their relationship with } \\
\text { region }\end{array}$ & $\begin{array}{l}\text { H3: The use of TIPS influences positively } \\
\text { marketing brand }\end{array}$ \\
\hline
\end{tabular}

Further research aims to develop a broader study considering other topics such as internationalization and relation with environment and market. And, also could provide more insights in order to validate the hypotheses formulated in this exploratory research.

\section{REFERENCES}

Ambler, T. (1997). HOW MUCH OF BRAND EQUITY IS EXPLAINED BY TRUST?. Management Decision, 35 (4), 283-92.

Asero, V.; Patti, S. (2009). DEVELOPING THE TOURIST MARKET THROUGH THE EXPLOITATION OF THE TYPICAL PRODUCTS. The Annals of Dunarea de Jos, University of Galati, Fascicle I/2, 
Year XV, 5-14.

Bhat, S.; Reddy, S.K. (1998). SYMBOLIC AND FUNCTIONAL POSITIONING OF BRANDS. Journal of Consumer Marketing, 5(1), 32-43.

Brush, C.G., de Bruin, A., Welter, F. (2009). A GENDER-AWARE FRAMEWORK FOR WOMEN'S ENTREPRENEURSHIP. International Journal of Gender and Entrepreneurship, 1(1), 8-24.

Carvalho, L., Williams, B. (2014). LET THE CORK FLY: CREATIVITY AND INNOVATION IN A FAMILY BUSINESS. International Journal of Entrepreneurship and Innovation, 15(2), 127-134.

Carvalho, L. (2014). FROM WINERY TO RURAL TOURISM EXPERIENCE: A PERFECT MARRIED COUPLE. IX Congresso Internacional sobre Turismo Rural e Desenvolvimento Sustentável (CITURDES), 9-10 setembro, São Paulo, Brasil.

Charters, S., Spielman, N. (2014). CHARACTERISTICS OF STRONG TERRITORIAL BRANDS: THE CASE OF CHAMPAGNE. Journal of Business Research, 67, 1461-1467.

Charters, S.; Mitchell, R.; Menival, D. (2011). THE TERRITORIAL BRAND IN WINE. 6th AWBR International Conference, 9-10 June, Bordeaux Management School, France.

De Bruin, A.; Brush, C.G.; Welter, F. (2006). INTRODUCTION TO THE SPECIAL ISSUE: TOWARDS BUILDING CUMULATIVE KNOWLEDGE ON WOMEN'S ENTREPRENEURSHIP. Entrepreneurship Theory and Practice, 3(5), 85-593.

De Chernatony, L. (1993). CATEGORIZING BRANDS: EVOLUTIONARY PROCESSES UNDERPINNED BY TWO KEY DIMENSIONS. Journal of Marketing Management, 9(2), 173-88.

De Chernatony, L.; MacDonald, M. (2003). CREATING POWERFUL BRANDS. Oxford, Butterworth Heinemann.

De Vette, C. (2011). THE GROWING IMPORTANCE OF WOMEN: FEMALE ENTREPRENEURSHIP. Master Thesis. Rotterdam, Erasmus Universiteit Rotterdam.

Dodds, W.B.; Monroe, K.B.; Grewal, D. (1991). EFFECTS OF PRICE, BRAND, AND STORE INFORMATION ON BUYERS' PRODUCT EVALUATIONS. Journal of Marketing Research, 28, August, 307-19.

European Commission (2014). STATISTICAL DATA ON WOMEN ENTREPRENEURS IN EUROPE, Brussels.

European Commission (2013). EUROPEAN NETWORK TO PROMOTE WOMEN'S ENTREPRENEURSHIP - WES REPORT 2012. Office for Official Publications of the European Union, Luxembourg.

Eisenhardt, K. (1989). BUILDING THEORIES FROM CASE STUDY RESEARCH. The Academy of Management Review, 14(4), 532-550.

Grabowski, G., \& Kuenzer, A. (2016). A PRODUÇÃO DO CONHECIMENTO NO CAMPO DA EDUCAÇÃO PROFISSIONAL NO REGIME DE ACUMULAÇÃO FLEXÍVEL.HOLOS, 6, 22-32. doi:https://doi.org/10.15628/holos.2016.4983

Hughes, K.; Jennings, J.; Brush, C., Carter, S.; Welter, F. (2012). EXTENDING WOMEN'S ENTREPRENEURSHIP RESEARCH IN NEW DIRECTIONS. Entrepreneurship Theory and Practice, 36, 429-442.

Hughes, K.D.; Jennings, J.E. (2012). GLOBAL WOMEN'S ENTREPRENEURSHIP RESEARCH: 
DIVERSE SETTINGS, QUESTIONS AND APPROACHES. Cheltenham/Northampton, U.K., Edward Elgar.

IFDEP - INSTITUTO PARA O FOMENTO E DESENVOLVIMENTO DO EMPREENDEDORISMO EM PORTUGAL (2014). EMPREENDEDORISMO FEMININO, UM OLHAR SOBRE PORTUGAL. IFDEP, Portugal.

Kelley, D. J.; Brush, C. G.; Greene, P. G.; Litovsky, Y. (2013). GLOBAL ENTREPRENEURSHIP MONITOR (GEM) 2012 WOMEN'S REPORT. London, U.K., Global Entrepreneurship Research Association (GERA).

Kotler, P.; Chandler, P. C. et al. (1994). MARKETING. Sydney, Prentice Hall.

Long, M.M.; Schiffman, L.G. (2000). CONSUMPTION VALUES AND RELATIONSHIPS: SEGMENTING THE MARKET FOR FREQUENCY PROGRAM. Journal of Consumer Marketing, $17(3), 214-32$.

McNamara, C. (1999). GENERAL GUIDELINES FOR CONDUCTING INTERVIEWS, Minnesota.

Ohe, Y.; Kurihara, S. (2013). EVALUATING THE COMPLEMENTARY RELATIONSHIP BETWEEN LOCAL BRAND FARM PRODUCTS AND RURAL TOURISM: EVIDENCE FROM JAPAN. Tourism Management, 35, 278-283.

Papadopoulos, N., Heslop, L. (2002). COUNTRY EQUITY AND COUNTRY BRANDING: PROBLEMS AND PROSPECTS. Journal of Product \& Brand Management, 9(4-5), 294-314.

Perrouty, J. P.; F. D'Hauteville et al. (2006). THE INFLUENCE OF WINE ATTRIBUTES ON REGION OF ORIGIN EQUITY: AN ANALYSIS OF THE MODERATING EFFECT OF CONSUMER'S PERCEIVED EXPERTISE. Agribusiness, 22(3), 323-341.

Sheth, J. N.; B. I. Newman, Gross, B.L. (1991). WHY WE BUY WHAT WE BUY: A THEORY OF CONSUMPTION VALUES. Journal of Business Research, 22, 159-175.

Van Ittersum, K.; M. J. Candel, et al. (2003). THE INFLUENCE OF THE IMAGE OF A PRODUCT'S REGION OF ORIGIN ON PRODUCT EVALUATION. Journal of Business Research, 56, 215-226.

Yin, R. (2004). CASE STUDY METHODS, COSMOS Corporation, Revised draft, January 20, 2004 available on http://www.cosmoscorp.com/docs/aeradraft.pdf.

Zeithhaml, V.A. (1998). CONSUMER PERCEPTIONS OF PRICE, QUALITY AND VALUE: MEANSEND MODEL AND SYNTHESIS OF EVIDENCE. Journal of Marketing, 52, July, 2-22.

ANNEX 1 - Interview Guidelines

- Brief description of the firm

- Profile and female entrepreneurship

- Female entrepreneurship and management style

- Understand the process of business creation

- TIPs and tourism

- Realize their relation with TIPs

- Measure the impact on local economy and regional tourism

- Products, brand and marketing

- Recognize the product/products developed and how they are related with wineries

- Understand how they develop the brand; regional marketing

- Future and challenges 